University of Nebraska - Lincoln

DigitalCommons@University of Nebraska - Lincoln

Nebraska Cooperative Fish \& Wildlife Research Nebraska Cooperative Fish \& Wildlife Research Unit -- Staff Publications

2002

\title{
Functional Group Change within and across Scales following Invasions and Extinctions in the Everglades Ecosystem
}

\author{
Elizabeth A. Forys \\ Eckerd College, forysea@eckerd.edu \\ Craig R. Allen \\ University of Nebraska-Lincoln, callen3@unl.edu
}

Follow this and additional works at: https://digitalcommons.unl.edu/ncfwrustaff

Part of the Other Environmental Sciences Commons

Forys, Elizabeth A. and Allen, Craig R., "Functional Group Change within and across Scales following Invasions and Extinctions in the Everglades Ecosystem" (2002). Nebraska Cooperative Fish \& Wildlife Research Unit -- Staff Publications. 91.

https://digitalcommons.unl.edu/ncfwrustaff/91

This Article is brought to you for free and open access by the Nebraska Cooperative Fish \& Wildlife Research Unit at DigitalCommons@University of Nebraska - Lincoln. It has been accepted for inclusion in Nebraska Cooperative Fish \& Wildlife Research Unit -- Staff Publications by an authorized administrator of DigitalCommons@University of Nebraska - Lincoln. 


\title{
Functional Group Change within and across Scales following Invasions and Extinctions in the Everglades Ecosystem
}

\author{
Elizabeth A. Forys ${ }^{1 *}$ and Craig R. Allen ${ }^{2}$
}

\begin{abstract}
${ }^{1}$ Environmental Studies Discipline, Eckerd College, 4200 54th Avenue South, St. Petersburg, Florida, 33711 USA; and ${ }^{2}$ United States Geological Survey, Biological Resources Division, South Carolina Cooperative Fish and Wildlife Research Unit, Room G27, Lehotsky Hall, Clemson University, Clemson, South Carolina 29634, USA
\end{abstract}

\begin{abstract}
Cross-scale resilience theory predicts that the combination of functional diversity within scales and functional redundancy across scales is an important attribute of ecosystems because it helps these systems resist minor ecological disruptions and regenerate after major disturbances such as hurricanes and fire. Using the vertebrate fauna of south Florida, we quantified how the loss of native species and invasion by nonnatives may alter functional group richness within and across scales. We found that despite large changes in species composition due to potential extinctions and successful invasions by nonnative species, functional group rich-
\end{abstract}

\section{INTRODUCTION}

Landscape change and habitat destruction, combined with the long-distance dispersal of species as a consequence of human activities, have resulted in rapid changes in the species composition of much of the Earth (Vitousek 1994). Native species may decline due to changes in ecosystem structure, and some newly introduced nonnatives may become established due to these same changes. Nonnative species may cause further decline of native species through predation, competition, and the transmittal of disease (Lodge 1993; Williamson 1996; Vitousek and others 1997).

Received 14 November 2000; accepted 20 December 2001.

*Corresponding author; e-mail: forysea@eckerd.edu ness will not change significantly within scales, there will not be any significant loss of overall redundancy of ecology function across scales, and overall body mass pattern will not undergo substantial change. However, the types of functions performed will change, and this change may have profound effects on not only the Everglades ecosystem but on the entire landscape of south Florida.

Key words: cross-scale resilience; diversity; functional group; ecosystem structure; endangered species; Everglades ecosystem; extinctions; Florida; invasive species; nonnative species.

When native species are lost, their ecological function (for example, pollination, dispersal, predation, parasitism) in an ecosystem may not be replaced by the nonnative species that become established. The effect of overall changes in species composition on ecosystem stability and resilience is not well understood. However, some species have crucial ("keystone") functions whose loss could lead to major ecological reorganization in the affected ecosystem.

There are several competing models that attempt to explain the relationship between species richness and ecological stability (MacArthur 1955; Ehrlich and Ehrlich 1981; Walker 1992; Lawton 1994). These models assume that a species has an ecological function and that the function of a species can be represented as occupying an area of multidimen- 
sional ecological space similar to a niche. Although the models differ in the role and importance of individual species, they agree that as species accumulate, they fill the ecological functional space, leading to an increase in ecological stability.

Recently, Peterson and others (1998) proposed a model of ecological resilience that expanded on these existing models by explicitly incorporating scale. They defined scale as a range of spatial and temporal frequencies where, at a particular ecological scale, higher frequencies may be perceived as noise and lower frequencies as background. Species interact with scale-dependent sets of ecological structures and processes that determine functional opportunities. At a particular ecological scale, the functions of species may overlap, but they will tend to differ as species evolve to avoid interspecific competition, and this process will increase diversity at a particular ecological scale. Across ecological scales, there is more overlap in ecological function because species are less likely to face competition from species that interact with the environment (for example, by foraging, competing, dispersing, defending territories) at other spatial and temporal scales. The combination of within-scale diversity of ecological function and across-scale redundancy (that is, reinforcement) adds to ecological resilience. The ecological function of a species loss at a particular scale can be offset by similar species that interact with the environment at a different scale. High within-scale diversity and across-scale redundancy are predicted to produce ecosystems that are capable of resisting minor ecological disruptions (for example, invasion by nonnatives) and regenerating after major disturbances (for example, hurricanes, fire).

We examined the within- and across-scale distribution of function for the vertebrate fauna of the south Florida Everglades ecosystem prior to and after extinctions and invasions. Since European colonization, this ecosystem has undergone severe habitat transformation and invasion by nonnative species. Species declines and extinctions have primarily resulted from habitat transformation, as well as interactions with nonnatives. Successful invasions have been aided by this same habitat transformation (Forys and Allen 1999; Allen and others 1999). For our analyses, we did not assume that all species that interact with the environment at the same scale directly interact themselves, but we did assume that invasions and extinctions are related to changes in landscape structure that result from changes in the processes that structure ecosystems at large scales. The main objective of our paper was to quantify how the cross-scale resilience of the Everglades ecoregion will be affected due to loss of native species and invasion by nonnatives. Specifically, we examine whether the changes in the fauna will alter functional group richness within ecological scales and redundancy across scales. Additionally, we tested if the overall body mass patterns of vertebrates would change after the large species turnover represented by invasions and extinctions.

\section{METHODS}

We used three primarily terrestrial vertebrate groups in our analyses: birds, herpetofauna (reptiles and amphibians), and mammals. Species distributions were obtained from museum records and published accounts (Ashton and Ashton 1988; Brown 1997; Kale and others 1992; Meshaka and others 2000). Only species that had established breeding populations in south Florida were included in the analysis. We used the boundaries of the Everglades subecoregion (Bailey 1983) that included portions of the following counties: Broward, Collier, Dade, Hendry, Lee, Monroe, and Palm Beach. Oceanic and deep-water aquatic species were excluded from the analysis because they interact with their environment differently from terrestrial species (Holling 1992) and may be trophically compartmentalized from terrestrial systems (Pimm and Lawton 1980).

To test our hypotheses, we assembled species lists for each taxonomic group before and after European colonization (Forys and Allen 1999; Allen and others 1999). A species was considered to be nonnative if it was introduced to south Florida by humans, or if it had invaded south Florida since European colonization. A species was considered to be endangered if it was listed by the state of Florida as being extinct, endangered, threatened, or a species of special concern (Florida Game and Freshwater Fish Commission 1997). Listed subspecies were not included unless they were the only subspecies occurring in south Florida, or if all subspecies were listed. The "preinvasion" species lists included all species that were considered to be native to south Florida, including all species on the state of Florida's endangered species list, even those that are currently extinct or nearly so. The "postinvasion" species lists assumed that all listed species will go extinct in the near future. This list included all nonlisted native species, established breeding nonnative species, and explicitly omitted currently listed species.

Within each taxonomic group, the pre and postinvasion species lists were further grouped by the spatial and temporal scale at which species interact with the environment, based upon discontinuities 
in body mass distributions (see Allen and others 1999). In most cases, data on vertebrate body masses were collected from published sources. For a portion of the herpetofauna, body mass was determined from unpublished field data or by weighing a sample $(n=10)$ of preserved museum specimens. Although some weight changes occur during the preservation process, these changes tend to be less than $10 \%$ (Haighton 1956). Discontinuities in the body mass distributions of the three taxa were determined by simulations that compared actual data with a null distribution established by estimating a continuous unimodal kernel distribution of the logtransformed data (Silverman 1981). Gaps were defined as areas between successive body masses that significantly exceeded the discontinuities generated by the continuous null distribution. A species aggregation was a grouping of three or more species with body masses not exceeding the expectation of the null distribution. It is assumed that species within an aggregation perceive and exploit their environment at similar ecological scales, and that those scales differ from species in other body mass aggregations (Peterson and others 1998; Allen and others 1999).

To determine the richness of ecological functions for each body mass aggregation, we classified species by functional groups using both foraging strata (for example, aquatic, fossorial, terrestrial, arboreal/foliage, bark, and aerial) and diet (herbivorous, omnivorous, insectivorous, and carnivorous) based on published species accounts (see Forys and Allen 1999) (Table 1). Functional group richness for each aggregation was determined by simply counting the number of different foraging strata/diet combinations present in each body mass aggregation.

To determine if there was an increase or decrease in the redundancy in functional groups across scales, we counted the number of body mass aggregations where at least one member of a given functional group was present preinvasion and compared this to the number of aggregations where it occurred postinvasion using a $t$-test. This analysis was performed separately for each taxonomic group and then by pooling data from all of the groups. Before performing any $t$-tests, we ran a Kolmogorov-Smirnov test (with Lilliefors' correction) to test data form normality of the estimated underlying population (SAS Institute 1989).

We tested if the body mass pattern would change from the historic condition to the hypothetical future condition by also determining the discontinuities in the hypothetical future vertebrate communities. To compare the historical and future body mass patterns within each taxonomic group, we
Table 1. Functional Groups Used to Classify the Vertebrate Fauna of South Florida Based on Foraging Strata and Diet

\begin{tabular}{lll}
\hline Diet & Foraging Strata & Abbreviation \\
\hline Carnivore & Aerial & CAe \\
Carnivore & Aquatic & CAq \\
Carnivore & Fossorial & CFO \\
Carnivore & Terrestrial & CTe \\
Herbivore & Aerial & HAe \\
Herbivore & Aquatic & HAq \\
Herbivore & Arboreal/Foliage & HAr \\
Herbivore & Terrestrial & HTe \\
Insectivore & Aerial & IAe \\
Insectivore & Aquatic & IAq \\
Insectivore & Arboreal/Foliage & IAr \\
Insectivore & Bark & IBa \\
Insectivore & Fossorial & IFo \\
Insectivore & Terrestrial & ITe \\
Omnivore & Aquatic & OAq \\
Omnivore & Arboreal/Foliage & OAr \\
Omnivore & Terrestrial & OTe \\
& & \\
\hline
\end{tabular}

first converted each list into a binary vector of log 10 body mass based on 0.01 sized bins, with a mass range equivalent to the extremes of the combined future and historic body mass comparisons. Body mass aggregations along the vector were coded as 1 and gaps as 0 , and the similarity of within taxon historic-future body mass structure was then compared in a $2 \times 2$ table with the chi-square statistic, and with phi correlation between the historic and future body mass vectors (PROC FREQ) (SAS Institute 1989). For the chi-square tests, the null hypothesis is that there are equal distributions of the variables (vectors) among four possible states (both data sets in the lump condition, both data sets in the gap condition, one data set in the lump condition while the other in gap condition, and vice versa); that is, the two groups are unrelated. The phi coefficient ranges from -1 to 1 . Values approaching -1 are strongly negatively correlated; values approaching 1 are strongly positively correlated.

\section{RESULTS}

Preinvasion, there were 191 terrestrial vertebrate species in south Florida (Table 2). Today, $21 \%$ of these species are on Florida's endangered species list. If all currently listed species go extinct and all of the currently established nonnative species persist, $46 \%$ of the fauna will be nonnative.

As indicated in previous studies (see Allen and others 1999), the body mass distributions were dis- 
Table 2. Body Mass Range, Number of Nonlisted Native Species, Listed Native Species, and Nonnative Species for the Vertebrate Fauna of the Everglades Ecosystem, and the Functional Group Richness and Shannon Diversity Index for each Body Mass Aggregation

\begin{tabular}{|c|c|c|c|c|c|c|}
\hline $\begin{array}{l}\text { Body Mass } \\
\text { Aggregation }\end{array}$ & $\begin{array}{l}\text { Body Mass } \\
\text { Range (g) }\end{array}$ & $\begin{array}{l}\text { Nonlisted } \\
\text { Natives }\end{array}$ & $\begin{array}{l}\text { Listed } \\
\text { Natives }\end{array}$ & Nonnatives & $\begin{array}{l}\text { Richness } \\
\text { Preinvasion }\end{array}$ & $\begin{array}{l}\text { Richness } \\
\text { Postinvasion }\end{array}$ \\
\hline \multicolumn{7}{|l|}{ Birds } \\
\hline 1 & $3.2-12.0$ & 10 & 0 & 0 & 3 & 3 \\
\hline 2 & $14.1-23.4$ & 8 & 3 & 2 & 5 & 5 \\
\hline 3 & $26.9-33.9$ & 5 & 0 & 4 & 4 & 5 \\
\hline 4 & $40.7-52.5$ & 7 & 2 & 3 & 3 & 3 \\
\hline 5 & $61.7-72.4$ & 7 & 0 & 1 & 4 & 5 \\
\hline 6 & 79.4-97.7 & 4 & 1 & 1 & 3 & 3 \\
\hline 7 & $109.6-131.8$ & 4 & 2 & 7 & 5 & 5 \\
\hline 8 & $147.9-213.8$ & 10 & 0 & 6 & 6 & 7 \\
\hline 9 & $245.5-38.02$ & 6 & 5 & 5 & 7 & 8 \\
\hline 10 & $446.7-724.4$ & 12 & 2 & 3 & 7 & 9 \\
\hline 11 & $871.0-1122.0$ & 5 & 3 & 2 & 4 & 5 \\
\hline 12 & $1479.1-2398.8$ & 5 & 2 & 1 & 2 & 3 \\
\hline 13 & $4786.3-5754.4$ & 1 & 2 & 2 & 3 & 2 \\
\hline Total & & 84 & 22 & 37 & & \\
\hline \multicolumn{7}{|l|}{ Herpetofauna } \\
\hline l & $0.2-0.4$ & 6 & 0 & 4 & 2 & 3 \\
\hline 2 & $1.3-4.1$ & 9 & 3 & 4 & 5 & 5 \\
\hline 3 & $5.0-15.9$ & 12 & 0 & 4 & 6 & 7 \\
\hline 4 & $19.1-60.3$ & 7 & 1 & 3 & 4 & 6 \\
\hline 5 & $81.3-141.3$ & 4 & 1 & 4 & 3 & 5 \\
\hline 6 & $195.0-257.0$ & 3 & 0 & 0 & 1 & 1 \\
\hline 7 & $446.7-2630.3$ & 2 & 2 & 2 & 3 & 3 \\
\hline Total & & 43 & 7 & 21 & & \\
\hline \multicolumn{7}{|l|}{ Mammals } \\
\hline 1 & $4.8-17.0$ & 8 & 1 & 1 & 3 & 3 \\
\hline 2 & $37.2-64.6$ & 3 & 2 & 0 & 4 & 2 \\
\hline 3 & $104.7-602.6$ & 4 & 3 & 3 & 5 & 4 \\
\hline 4 & $933.3-1349.0$ & 2 & 2 & 1 & 2 & 1 \\
\hline 5 & $4466.8-24547$ & 6 & 1 & 4 & 3 & 3 \\
\hline 6 & $63095-151356$ & 1 & 2 & 1 & 3 & 2 \\
\hline Total & & 24 & 11 & 10 & & \\
\hline
\end{tabular}

continuous and thus composed of multiple aggregations. The number of body mass aggregations ranged from six for the mammals to 13 for the birds (Allen and others 1999) (Table 2 and Appendix).

Across body mass aggregations, there were many changes between pre- and postinvasion in the number of species belonging to each functional group (Figure 1). For the birds, the largest losses occurred in the number of carnivores of all strata. The terrestrial carnivore functional group will be completely lost if the crested caracara (Caracara plancus) goes extinct. The largest increases in the bird fauna postinvasion will be aerial and terrestrial herbivores. Most of the nonnative aerial herbivores are psittacids such as the increasingly abundant monk parakeet (Aratinga weddelii). The increase in the terrestrial herbivores can be explained by the large number of nonnative columbidae that have successfully colonized south Florida.

There were few large losses in the herpetofauana functional groups (Figure 2), but several poorly represented groups, such as the fossorial carnivores (for example, pine snake, Pituophis melanoleucus) and terrestrial herbivores (for example, gopher tortoise, Gopherus polyphemus), will not be replaced by ecologically similar species. Three new functional groups will be added as more iguanas, anoles (for instance, knight anole, Anolis equestris, an arboreal herbivore), and the giant toad (Bufo marinus) become further established. In addition, there will be large increases in the number of arboreal and terrestrial insectivores because a large number of gec- 


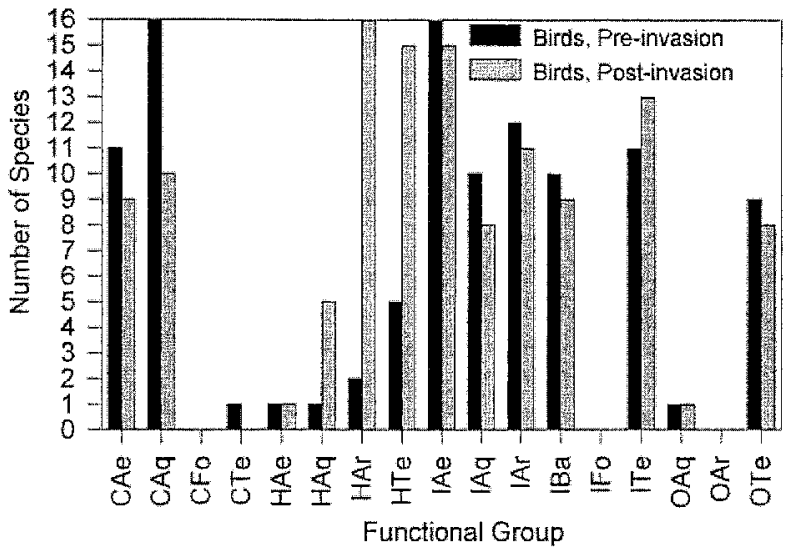

Figure 1. Comparison of the number of species belonging to each functional group across all body mass aggregations pre- and postinvasion for the birds of the Everglades ecosystem. Explanations for the functional group abbreviations are given in Table 1 .

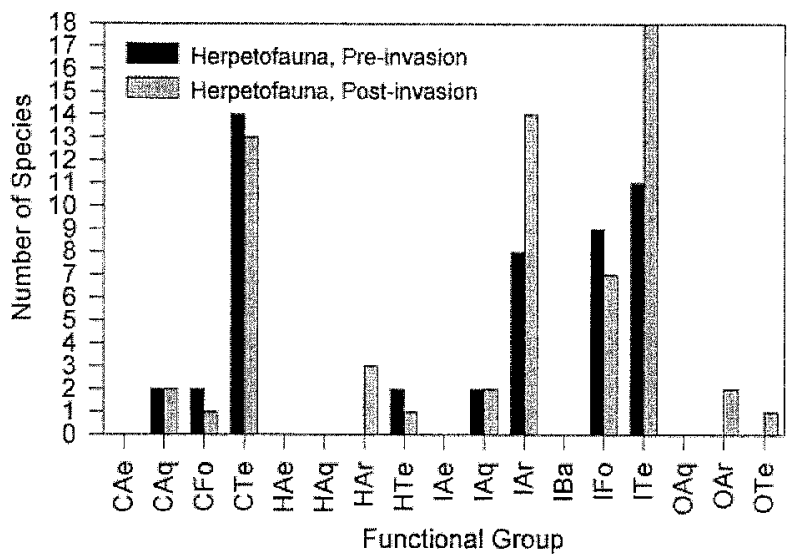

Figure 2. Comparison of the number of species belonging to each functional group across all body mass aggregations pre- and postinvasion for the herpetofauna of the Everglades ecosystem. Explanations for the functional group abbreviations are given in Table 1 .

kos and treefrogs are currently established and will likely continue to expand (for example, Cuban treefrog, Osteopilus septentrionalis). The least dramatic changes will be seen in the mammalian fauna (Figure 3), where there are several changes in the number of species in each functional group but no obvious pattern.

Within each body mass aggregation, there were large changes between the pre-and postinvasion species lists in terms of species composition and functional group membership. However, the $t$-tests comparing the mean functional group richness in body mass aggregations pre- and postinvasion were not significantly different for each taxonomic group

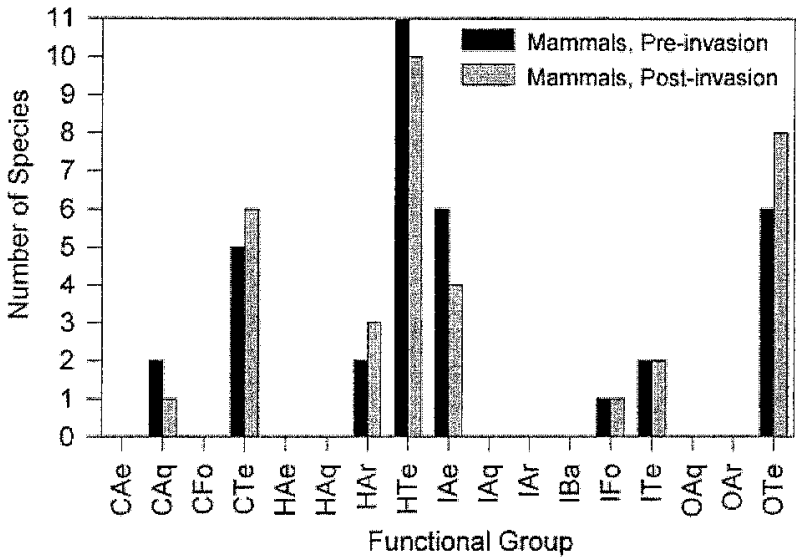

Figure 3. Comparison of the number of species belonging to each functional group across all body mass aggregations pre- and postinvasion for the mammals of the Everglades ecosystem. Explanations for the functional group abbreviations are given in Table 1 .

Table 3. Result of $t$-tests Comparing Functional Group Richness Preinvasion and Postinvasion for Each Terrestrial Vertebrate Group in South Florida and for All Groups Combined

\begin{tabular}{lrll}
\hline $\begin{array}{l}\text { Taxonomic } \\
\text { Group }\end{array}$ & \multicolumn{1}{l}{$t$} & $P$ & $\begin{array}{l}\text { Degrees of } \\
\text { Freedom }\end{array}$ \\
\hline Birds & -0.73 & 0.47 & 24 \\
Herpetofauna & -0.85 & 0.41 & 12 \\
Mammals & 1.39 & 0.20 & 10 \\
Combined & -0.61 & 0.55 & 50 \\
\hline
\end{tabular}

or for all of the groups combined (Table 3). The data for all of these tests did not significantly deviate from normal $(P>0.05)$. Statistical power was relatively low for the tests of each taxonomic group (0.07-0.15); however, power was higher for the analyses of all groups combined (0.49). Additionally, neither invasions nor extinctions clustered within one or a few body mass aggregations (Forys and Allen 1999).

Despite these large changes, the overall number of body mass aggregations that had at least one member of a functional group (that is, cross-scale redundancy) was not significantly different preand postinvasion for any of the taxonomic groups or the data combined (Table 4). Some entire functional groups were lost across all body mass aggregations, but new members of new functional groups invaded and were present in an equal number of body mass aggregations. Cross-scale ecological redundancy was the same, but the functional groups involved changed. 
Table 4. Results of $t$-tests Comparing the Mean Number of Body Mass Aggregations That Had at Least One Member of a Functional Group Pre- and Postinvasion

\begin{tabular}{|c|c|c|c|c|c|}
\hline Taxonomic Group & $\begin{array}{l}\text { Average \# (std) } \\
\text { of Body Mass } \\
\text { Aggregations } \\
\text { Preinvasion }\end{array}$ & $\begin{array}{l}\text { Average \# (std) } \\
\text { of Body Mass } \\
\text { Aggregations } \\
\text { Postinvasion }\end{array}$ & $t$ & $P$ & Degrees of Freedom \\
\hline Birds & $3.24(2.54)$ & $3.53(2.67)$ & -0.33 & 0.74 & 32 \\
\hline Herpetofauna & $1.41(1.80)$ & $1.71(1.93)$ & -0.46 & 0.65 & 32 \\
\hline Mammals & $1.18(1.59)$ & $0.88(1.36)$ & 0.58 & 0.57 & 32 \\
\hline Combined & $1.94(2.19)$ & $2.04(2.31)$ & -0.22 & 0.83 & 100 \\
\hline
\end{tabular}

Mam mals

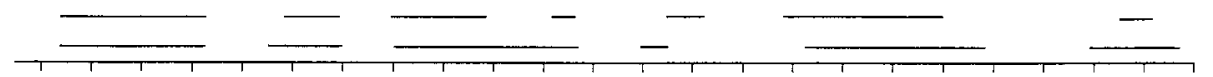

0.60 .81 .01 .21 .41 .61 .82 .02 .22 .42 .62 .83 .03 .23 .43 .63 .84 .04 .24 .44 .64 .85 .05 .2

$\mathrm{B}$ irds

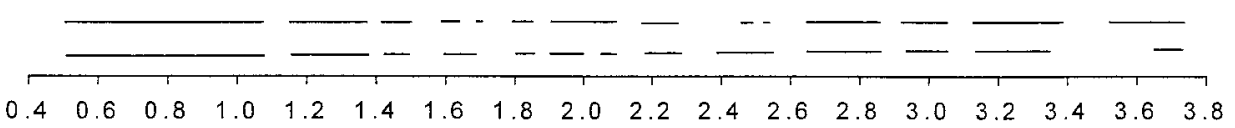

Herpetofauna

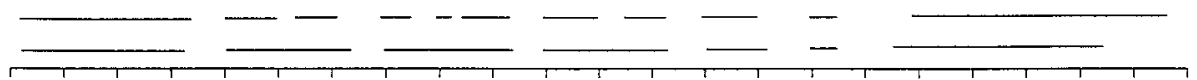

Figure 4. Comparison of body mass pattern of the Everglades ecosystem mammals, herpetofauna, and birds. The upper horizontal lines under each taxonomic heading are the vectors of the future body mass distribution; the lower horizontal lines are the historic pattern. Horizontal lines represent body mass aggregations ("lumps").
Despite a large turnover in species, the alternative hypothesis of general association between the historic and future body mass patterns was supported for each taxon $(P<0.001)$. Concordance between the historic versus future comparisons was $73 \%$ for mammals and herpetofauna, and $88 \%$ for birds. Future body mass pattern will be very similar to the historic structure; invasive species do not fill in the gaps, and gap and lump structure remains little changed (Figure 4). Phi coefficients indicated positive associations in all historic-future comparisons (mammals, phi $=0.477$; herpetofauna, $\mathrm{phi}=$ 0.367 ; birds, phi $=0.704$ ). Phi correlation has no associated probability level, but Fleiss (1981) suggested that values of greater than \pm 0.30 are "significant."

\section{DisCuSSION}

Despite the large differences in the pre- and postinvasion species communities in the Everglades, both the number of functional groups in a given body mass aggregation and distribution of functional groups across different body mass aggrega- tions remained similar pre- and postinvasion. Our analysis suggests that cross-scale resilience will not be lost in the Everglades due to these large changes in fauna. This is somewhat surprising because human influences on ecosystems are generally assumed to result in the simplification of these communities (see Hughes 1994; Regier and Baskerville 1986) and therefore loss of crossscale resilience (Peterson and others 1998). It may be that although the effect of some nonnative species on native species is to reduce overall species diversity (for example, Cuban tree frog predation on native hylids), the overall net effect of the establishment of nonnative species in the Everglades ecoregion has offset losses of species due to other human influences (for example, habitat destruction, fragmentation, degradation). This result indicates that body mass aggregations and functional group diversity both play a role in determining the rules for assembling ecosystem or landscape level biota. Similar results have been found by researchers studying the body-size patterns of species at large ecological scales (Cody 1975; Diamond 1975; Brown and Nicoletto 1991). 
In addition, the overall pattern of body mass aggregations has not changed significantly despite an enormous change in species composition from historic to predicted future conditions. Successfully established species have had body masses that place them at the edge of body mass aggregations rather than randomly in terms of the overall body mass distribution (Allen and others 1999). We suggest that the relationship among ecological processes, landscape structure across scales, and animals is robust and resilient to species turnover (Havlicek and Carpenter 2001), due to strong self-organization among these components.

However, this does not imply that there will not be ecological consequences to this species turnover. Currently, the entire Everglades ecosystem is in a state of transition, with plant and animal composition changing in tandem, or with a lag, with changes in structure resulting from human alteration of key processes, largely hydrology. As tidally influenced wetlands and pinelands are replaced with retention ponds and subdivisions, species such as wood storks (Mycteria americana) and indigo snakes (Drymarchon corais) are becoming less abundant, while species like muscovy ducks (Cairina moschata) and giant toads (Bufo marinus) flourish. Although the functional group richness within each body mass aggregation has not decreased, the specific functional groups that comprise this richness and redundancy will change dramatically. The loss of some functional groups may have unforeseen consequences for the Everglades and potentially for the entire landscape of south Florida.

\section{ACKNOWLEDGMENTS}

This manuscript was improved by comments from G. Peterson and C. Stow. The South Carolina Cooperative Fish and Wildlife Research Unit is jointly supported by a cooperative agreement among the USGS/BRD, the South Carolina Department of Natural Resources, Clemson University, and the Wildlife Management Institute.

\section{REFERENCES}

Allen CR, Forys EA, Holling CS. 1999. Body mass patterns predict invasions and extinctions in transforming landscapes. Ecosystems 2:114-21.

Ashton RE Jr, Ashton PS. 1988. Handbook of reptiles and amphibians of Florida. Pts 1-3. Miami: Windward.

Bailey RG. 1983. Delineation of ecosystem regions. Environ Manage 7:365-73.

Brown JH, Nicoletto PF. 1991. Spatial scaling of species compositions: body masses of North American land mammals. Am Nat 138:1478-512.

Brown LW. 1997. Mammals of Florida. Miami: Windward. Cody ML. 1975. Towards a theory of continental species diversities: bird distributions over Mediterranean habitat gradients. In: Cody ML, Diamond JM editors. Ecology and evolution of communities. Cambridge (MA): Harvard University Press. p 214-57.

Diamond JM. 1975. Assembly of species communities. In: Cody ML, Diamond JM editors. Ecology and evolution of communities. Cambridge (MA): Harvard University Press. p 342-444.

Ehrlich PR, Ehrlich AH. 1981. Extinction: the causes and consequences of the disappearance of species. New York: Random House.

Fleiss JL. 1981. Statistical methods for rates and proportions, 2nd edition. New York: John Wiley and sons.

Florida Game and Freshwater Fish Commission. 1997. Official list of endangered and potentially endangered fauna and flora in Florida. Tallahassee (FL): Florida Game and Freshwater Fish Commission.

Forys EA, Allen CR. 1998. Biological invasions and deletions: community change in south Florida. Biol Conserv 87:341-7.

Haighton R. 1956. The life history of the slimy salamander, Plethodon glutinosus, in Florida. Copeia 1956:75-93.

Havlicek TD, Carpenter SR. 2001. Pelagic species size distributions in lakes: are they discontinuous? Limnol Oceanogr 46:1021-33.

Holling CS. 1992. Cross-scale morphology, geometry, and dynamics of ecosystems. Ecol Monogr 62:447-502.

Hughes TP. 1994. Catastrophers, phase shifts, and large-scale degradation of a Caribbean coral reef. Science 265:1547-51.

Kale HW II, Pranty B, Stith BM, Biggs CW. 1992. The atlas of breeding birds of Florida. Final report. Nongame Wildlife Program. Tallahassee (FL): Florida Game and Freshwater Fish Commission.

Lawton JH. 1994. What do species do in ecosystems? Oikos 71:367-74.

Lodge DM. 1993. Species invasions and deletions: community effects and responses to climate and habitat change. In: Kareiva PM, Kingsolver JG, Huey RB, editors. Biotic interactions and global change. Sunderland (MA): Sinauer Associates. p 367-87.

MacArthur RH. 1955. Fluctuations of animal populations and a measure of community stability. Ecology 36:533-6.

Meshaka WE Jr, Loftus WF, Steiner T. 2000. The herpetofauna of Everglades National Park. Fla Sci 63:84-103.

Peterson GD, Allen CR, Holling CS. 1998. Ecological resilience, biodiversity, and scale. Ecosystems 1:6-18.

Pimm SL, Lawton JH. 1980. Are food webs compartmented? J Animal Ecol 49:879-98.

Regier HA, Baskerville FL. 1986. Sustainable redevelopment of regional ecosystem degraded by exploitive development. In: Munn WC, Munn RE, editors. Sustainable development of thebiosphere. Cambridge (MA): Cambridge University Press. p 75-101.

SAS Institute. 1989. SAS/STAT user's guide. Version 6. 4th ed. Cary (NC): SAS Institute.

Silverman BW. 1981. Using kernel density estimates to investigate multimodality. J R Stat Soc [B] 43:97-9.

Vitousek PM. 1994. Beyond global warming: ecology and global change. Ecology 75:1861-76.

Vitousek PM, Mooney HA, Lubchenco J, Melillo JM. 1997. Human domination of Earth's ecosystems. Science 277:494-9.

Walker B. 1992. Biological diversity and ecological redundancy. Conserv Biol 6:18-23.

Williamson M. 1996. Biological invasions. New York: Chapman \& Hall. 
Appendix Species Lists of Taxa, Subdivided by Status (Listed Native, Nonlisted Native, Nonnative), in Order of Body Mass.

Birds, listed natives-Ammodramus savannarum (ITe, B2), Aimophilia aestivalis (HTe, B2), Ammodramus maritimus (ITe, B2), Picoides borealis (IBa, B4), Lanius ludovicianus (IAe, B4), Aphelocoma coerulescens (OTe, B6), Conuropsis carolinensis (HAr, B7), Falco sparverius (IAe, B7), Columba leucocphala (HAr, B9), Florida caerulea (CAq, B9), Egretta thula (CAq, B9), Egretta tricolor (CAq, B9), Rostrhamus sociabilis (CAe, B9), Egretta rufescens (CAq, B10), Campephilus principalis (IAr, B 10), Caracara (Polyborus) plancus (CTe, B11), Eudocimus albus (IAq, B11), Aramus guarauna (IAq, B 11), Ajaia ajaja (CAq, B12), Mycteria ameriana (CAq, B12), Grus Canadensis (OTe, B13)

Birds, nonlisted natives-Archilochus colubris (HAe, Bl, Bl), Polioptila caerulea (IAr, Bl, B1), Dendroica discolor (IAr, Bl, B1), Parula americana (IAr, B1, B 1), Dendroica dominica (IBa, B1, Bl), Dendroica petechia (IAr, B1, B1), Geothlypis trichas (IAr, B1, B 1), Sitta pusilla (IBa, B 1, B 1), Vireo griseus (IAr, B1, B 1), Dendroica pinus (IBa, B 1, B 1), Protonotaria citrea (IBa, B2, B2), Stelgidopteryx serripennis (IAe, B2, B2), Hirundo rustica (IAe, B2, B2), Vireo olivaceus (IAe, B2, B2), Vireo altiloquus (IAr, B2, B2), Thryothorus ludovicianus (ITe, B2, B2), Parus bicolor (IAr, B2, B2), Chaetura pelagica (IAe, B2, B2), Picoides pubescens (IBa, B3, B3), Piranga rubra (IAr, B3, B3), Columbigallina passerina (HTe, B3, B3), Sialia sialis (IAe, B3, B3), Myiarchus crinitus (IAe, B3, B3), Pipllo erythrophthalmus (ITe, B4, B4), Tyrannus tyrannus (IAe, B4, B4), Tyrannus dominicensis (IAe, B4, B4), Cardinalis cardinalis (ITe, B4, B4), Mimus polyglottos (ITe, B4, B5), Progne subis (IAe, B4, B5), Agelaius phoeniceus (ITe, B4, B5), Chordeiles minor (IAe, B5, B6), Melanerpes carolinus (IBa, B5, B6), Coccyzus minor (IAr, B5, B6), Coccyzus americanus (IAr, B5, B6), Picoides villosus (IBa, B5, B6), Toxostoma rufum (OTe, B5, B6), Melanerpes erythrocephalus (IBa, B5, B6), Ixobrychus exilis (CAq, B6, B7), Cyanocitta cristata (OTe, B6, B7), Stumella magna (ITe, B6, B7), Charadrius vociferous (ITe, B6, B7), Quiscalus quiscula (OTe, B7, B7), Zenaida macroura (HTe, B7, B7), Caprimulgus carolinensis (IAe, B7, B7), Colaptes auratus (ITe, B7, B7), Ceryle alcyon (CAq, B8, B8), Speotyto (Athene) cunicularia (IAe, B8, B8), Himantopus mexicanus (IAq, B8, B8), Quiscalus major (OTe, B8, B8), Colinus virginianus (HTe, B8, B8), Otus asio (IAe, B8, B8), Scolopax minor (ITe, B8, B8), Porphyrula martinica (OTe, B8, B8), Butorides virescens (CAq, B8, B8), Catoptrophorus semipalmatus (IAq, B8, B8), Corvus ossifragus (OTe, B9, B9), Dryocopus pileatus (IBa, B9, B9), Rallus longirostris (IAq, B9, B9), Gallinula chloropus (HAq, B9, B9), Elanus leucurus (CAe, B9, B9), Rallus elegans (IAq, B9, B10), Podilymbus podiceps (IAq, B10, B11), Elanoides forficatus (IAe, B10, B11), Corvus brachyrhynchos (OTe, B10, B11), Buteo brachyurus (CAe, B10, B11), Tyto alba (CAe, B10, B11), Buteo lineatus (CAe, B10, B11), Lophodytes cucullatus (CAq, B10, B11), Plegadis falcinellus (IAq, B10, B11), Fulica americana (OAq, B10, B11), Nyctanassa violacea (IAq, B 10, B11), Botaurus lentiginosus (CAq, B10, B11), Strix varia (CAe, B10, B11), Casmerodius albus (CAq, B 11, B 12), Nycticorax nycticorax (CAq, B11, B 12), Anas fulvigula (IAq, B 11, B12), Bubo virginianus (CAe, B11, B12), Buteo jamaicensis (CAe, B11, B12), Cathartes aura (CAe, B12, B13), Pandion haliaetus (CAq, B12, B13), Phalacrocorax auritus (CAq, B12, B13), Coragyps atratus (CAe, B12, B13), Ardea herodias (CAq, Bl2, B13), Meleagris gallopavo (HTe, B13, B14)

Birds, nonnatives-Hirundo fulva (IAe, B2), Carpodacus mexicanus (HTe, B2), Pyconotus jocosus (HAr, B3), Passer domesticus (HTe, B3), Melopsittacus undulatus (HTe, B3), Molothrus bonariensis (HTe, B3), Paroaria coronata (HAr, B4), Molothrus ater (ITe, B4), Icterus pectoralis (HAr, B4), Brotogeris versicoluras (HAr, B7), Stumus vulgaris (ITe, B7), Mylopsitta monachus (HAr, B7), Crotophaga ani (ITe, B7), Aratinga weddellii (HAr, B7), Acridotheres tristis (O Te, B7), Psittacula krameria (HAr, B7), Nandaynus nenday (HAr, B7), Streptopelia risoria (HTe, B7), Streplopelia decaoto (HTe, B8), Zenaida asiatica (HTe, B8), Aratinga acuticaudata (HAr, B8), Gracula religiosa (HAr, B8), Aratinga erythrogenys (HAr, B8), Aratinga mitrata (HAr, B8), Amazona viridigensalis (HAr, B9), Amazona amazonica (HAr, B10), Bubulcus ibis (ITe, B10), Ara severa (HAr, B10), Columba livia (HTe, B10), Francolinus francolinus (HTe, B11), Amazona oratrix (HAr, B11), Dendrocygna biocolor (HAq, B 11), Dendrocygna autumnalis (HTe, B 12), Anas platyrhynchos (HAq, B 12), Cairina moschata (HAq, B 13), Branta canadensis canadensis (HAq, B 14), Pavo cristatus (HTe, Bl4)

Herpetofauna, listed natives_Eumeces egregious (IFo, B2), Tantilla oolitica (IFo, B2), Seloperus woodi (ITe, B2), Rana capito (IFo, B4), Pituophis melanoleucus (CFo, B5), Drymarchon corais (CTe, B7), Gopherus polyphemus (HTe, B7)

Herpetofauna. nonlisted natives-Pseudacris ocularis (ITe, B 1, B 1), Hyla squirella (IAr, B 1, B 1), Acris gryllus (ITe, Bl, B1), Eurycea quadridigita (ITe, B1, B 1), Pseudacris nigrita (ITe, B 1, B 1), Scincella laterale (ITe, B1, B1), Bufo quercicus (ITe, B2, B2), Gastrophryne carolinensis (IFo, B2, B2), Hyla crucifer (ITe, B2, B2), Tantilla relicta (IFo, B2, B2), Anolis carolinensis (IAr, B2, B2), Anolis distichus (IAr, B2, B3), Hyla femoralis (IAr, B2, B3), Diadophis punctatus (CTe, B2, B3), Rana sphenocephala (IAq, B2, B3), Hyla cinerea (IAr, B3, B4), Storeria dekayi (ITe, B3, B4), Farancia abacura (CAq, B3, B4), Cnemidophorus sexlineatus (ITe, B3, B5), Cemophora coccinea (CTe, B3, B5), Eumeces inexpectatus (IAr, B3, B6), Bufo terrestris (ITe, B3, B6), Thamnophis sauritus (CTe, B3, B6), Rana grylio (IAq, B3, B6), Terepene carolina (HTe, B3, B6), Thamnophis sirtalis (CTe, B3, B6), Hyla gratiosa (IAr, B3, B6), Opheodrys aestivus (IAr, B4, B7), Sistrurus miliarius (CTe, B4, B7), Scaphiopus holbrooki (IFo, B4, B7), Lampropeltis triangulum (CTe, B4, B7), Micrurus fulvius (CFo, B4, B8), Ophisaurus compressus (IFo, B4, B8), Ophisaurus ventralis (IFo, B4, B8), Ophisaurus attenuatus (IFo, B5, B9), Coluber constrictor (CTe, B5, B9), Elaphe guttata (CTe, B5, B9), Heterondon platyrhinos (CTe, B5, B9), Elaphe obsolèta (CTe, B6, B 10), Lampropeltis getulus (CTe, B6, B10), Masticophis flagellum (CTe, B6, B10), Crotalus adamanfeus (CTe, B7, B11), Aqkistrodon piscivorus (CAq, B7, B11) 


\section{Appendix (Continued)}

Herpetofauna. nonnatives-Eleutherodactylus planirostris (ITe, B1), Sphaerodactylus notatus (ITe, B 1), Ramphotyphlops braminus (IFo, B1), Sphaerodactylus argus (IAr, B1), Spaerodactylus elegans (IAr, B2), Gonatodes albogulari (IAr, B2), Hemidactylus gamoti (IAr, B3), Hemidactylis turcicus (IAr, B3), Anolis sagrei (ITe, B4), Eleutherodactylus coqui (ITe, B4), Anolis cristatellus (OAr, B5), Cnemidophorus lemniscatus (ITe, B6), Osteopilus septentrionalis (IAr, B7), Anolis garmani (OAr, B7), Leiocephalus carinatus (ITe, B7), Anolis equestris (HAr, B7), Basiliscus vittatus (ITe, B9), Ameiva ameiva (ITe, B9), Bufo marinus (OTe, B10), Ctenosaura pectinata (HAr, B11), Iguana iguana (HAr, B 11)

Mammals. listed natives_Lasiurus intermedius (IAe, B1), Peromyscus floridanus (OTe, B2), Eumops glaucinus (IAe, B2), Mustela frenata (CTe, B3), Neofiber alleni (HTe, B3), Neotoma floridana (HTe, B3), Mustela vison (CAq, B4), Sciurus niger (HTe, B4), Canis rufus (CTe, B5), Felis concolor (CTe, B6), Ursus americanus (OTe, B6)

Mammals. nonlisted natives-Pipistrellus subflavus (IAe, Bl, Bl), Cryptotis parva (ITe, B 1, Bl), Nycticeius humeralis (IAe, B1, B1), Lasiurus seminolus (IAe, B1, B1), Peromyscus polionotus (HTe, Bl, Bl), Reithrodontomys humulis (HTe, Bl, Bl), Tadarida brasiliensis (IAe, B1, B1), Blarina carolinensis (ITe, B1, B1), Peromyscus gossypinus (HTe, B2, B2), Oryzomys palustris (HTe, B2, B2), Glaucomys volans (HAr, B2, B2), Scalopus aquaticus (IFo, B3, B3), Sigmodon hispidus (HTe, B3, B3), Sciurus carloinensis (HAr, B3, B4), Spilogale putorius (OTe, B3, B4), Sylvilagus floridanus (HTe, B4, B5), Sylvilagus palustris (HTe, B4, B5), Mephitis mephitis (OTe, B5, B6), Urocyon cinereoargenteus (CTe, B5, B6), Didelphis virginiana (OTe, B5, B6), Lutra canadensis (CAq, B5, B6), Procyon lotor (OTe, B5, B6), Lynx rufus (CTe, B5, B6), Odocoileus virginianus (HTe, B6, B7)

Mammals. nonnatives-Mus musculus (HTe, B1), Rattus rattus (OTe, B3), Rattus norvegicus (OTe, B3), Sciurus aureogaster (HAr, B4), Lepus californicus (HTe, B5), Felis catus (CTe, B6), Dasypus novemcinctus (OTe, B6), Vulpes vulpes (CTe, B6), Canis latrans (CTe, B6), Canis familiaris (CTe, B6), Sus scrofa (OTe, B7)

Following each species name are its functional group (see Table 1 for abbreviations) and its body mass aggregation group. For nonlisted natives, the body mass aggregation group preinvasion is followed by the body mass aggregation postinvasion. 